\title{
BIMBINGAN KELOMPOK DENGAN TEKNIK PSIKODRAMA TERHADAP KEMANDIRIAN BELAJAR
}

\author{
Group Coaching With Psikodrama Techniques On Learning Independence \\ Oleh: Annisa Ul Khusna*, Arri Handayani**, dan Gregorius Rahastono Ajie*** \\ e-mail: Anisaulkhusna30@gmail.com
}

\begin{abstract}
ABSTRAK
Penelitian ini dilatarbelakangi oleh rendahnya kemandirian belajar pada siswa. Tujuan dari penelitian ini adalah untuk mengetahui pengaruh layanan bimbingan kelompok dengan teknik psikodrama terhadap kemandirian belajar siswa kelas X SMK PGRI 2 Taman Pemalang. Jenis penelitian ini adalah penelitian kuantitatif. Metode yang digunakan adalah true experimental, sampel yang diambil sebanyak 20 siswa yang dibagi menjadi dua kelompok yaitu kelompok eksperimen dan kelompok kontrol dengan menggunakan teknik pengambilan sampel cluster random sampling. Data dalam penelitian diperoleh melalui instrument penelitian skala kemandirian belajar. Dari hasil perhitungan pre-test menunjukan rata-rata kelompok eksperimen sebesar 73,0 sedangkan hasil post-test menunjukan rata-rata kelompok eksperimen sebesar 90,8. Terjadi peningkatan rata-rata kelompok eskperimen sebesar 17,8 poin. Pada perhitungan uji-t diperoleh hasil thitung $(2,543)$ dan ttabel diperoleh pada taraf signifikansi 5\% sebesar $(2,101)$. Maka dapat disimpulkan ada pengaruh layanan bimbingan kelompok dengan teknik psikodrama terhadap kemandirian belajar siswa kelas XI SMK PGRI 2 Taman Pemalang.
\end{abstract}

Kata kunci: Layanan Bimbingan Kelompok Dengan Teknik Psikodrama, Kemandirian Belajar

\section{ABSTRACT}

This research is backed by the low self-reliance learning in students. The purpose of this research is to know the influence of group guidance services by Psychodrama techniques developing the independence of learning class X students SMK PGRI 2 Taman Pemalang. This type of research is quantitative research. The method used is true experimental, the samples taken as many as 20 students were divided into two groups: the experiment Group and the control group using the random sampling cluster sampling technique. The Data in the study was obtained through research instrument scale learning independence. The pre-test results showed an average experiment group of 73.0 while the post-test results showed an average experiment group of 90.8. An increase in the average group increased by 17.8 points. In the calculation of test-T obtained Thitung result (2.543) and this obtained at a rate of significance $5 \%$ (2.101). Then can be concluded there is the influence of group guidance services with psychodrama techniques on the independence of learning students grade XI SMK PGRI 2 Taman Pemalang.

Keywords: Group guidance service with psycodrama techniques, independence of learning

Annisa Ul Khusna*, Arri Handayani**, dan Gregorius Rahastono Ajie***

Bimbingan dan Konseling

Universitas PGRI Semarang 


\section{PENDAHULUAN}

Pada dasarnya manusia dilahirkan sebagai makhluk pembelajar. Tugas, tanggung jawab, dan panggilan pertama seorang manusia adalah menjadi pembelajar. Manusia terus menerus belajar yang berfungsi mempertinggi pengetahuan sosial yang sangat kompleks. Belajar bukanlah proses menyerap pengetahuan yang sudah dipelajari. Namun belajar adalah sebuah proses dimana siswa diharuskan aktif dalam kegiatan pembelajaran.Maslow (dalam Jamaris, 2013:163), mengemukakan bahwa anak belajar bukan karena dipaksa untuk belajar, akan tetapi belajar berdasarkan keinginannya untuk mengetahui sesuatu yang ada di lingkungannya. Oleh karena itu dibutuhkan kemandiriansiswa dalam belajar baik sendiri maupun bersama teman-temannya untuk mengembangkan potensinya masing-masing dalam belajar. Menurut Desmita (2014: 185), kemandirian merupakan kemampuan untuk mengendalikan dan mengatur pikiran, perasaan, dan tindakan sendiri secara bebas serta berusaha sendiri untuk mengatasi perasaan-perasaan malu dan keragu-raguan. Dengan kemandirian, siswa diharapkan akan lebih bertanggung jawab terhadap dirinya sendiri.Dalam pendidikan juga bertujuan untuk mengembangkan potensi siswa agar menjadi manusia yang beriman dan bertakwa kepada Tuhan Yang Maha Esa, berakhlak mulia, berilmu, kreatif, menjadi warga Negara yang demokratis, bertangung jawab serta mandiri. Penjabaran fungsi pendidikan di atas menyatakan bahwa kemandirian siswa menjadihal yang penting dan perlu dicapai dalam sebuah proses pendidikan. Aspek kemandirianyang menjadi tujuan pendidikan tentunya bukan saja kemandirian secara umum, namun juga kemandirian dalam belajar yang merupakan bagian dari pendidikan itu sendiri.

Menurut Rusman (2010: 359) kemandirian belajar adalah perilaku siswa dalam mewujudkan kehendak atau keinginannya secara nyata dengan baik dengan tidak bergantung pada orang lain. Dalam hal ini adalah siswa tersebut mampu melakukan belajar sendiri, dapat menentukan cara belajar efektif, mampu melaksanakan tugas-tugas belajar dengan baik dan mampu untuk melakukan aktivitas belajar secara mandiri. Dari pengertian kemandirian belajar di atas maka kemandirian belajar adalah aspek yang sangat penting dalam dunia pendidikan. Siswa yang tidak memiliki kemandirian belajar akan sangat sulit untuk bertanggung jawab dalam segala hal, terutama dalam proses pembelajaran, selain itu siswa tidak bisa mengambil keputusannya sendiri dan tidak mempunyai gagasan, ide, dan inisiatif dalam setiap permasalahan yang dihadapi.

Menurut Negoro (2008: 17) bahwa ciri-ciri kemandirian belajar dibagi menjadi lima indikator yaitu 1) memiliki kebebasan dalam berinisiatif, 2) memiliki rasa percaya diri, 3) mampu mengambil keputusan, 4) dapat bertanggung jawab, dan 5) mampu menyesuaikan diri dengan lingkungan.

Sesuai dengan hasil AKPD (Analisis Kebutuhan Peserta didik) yang peneliti berikan kepada siswa-siswi kelas X SMK PGRI 2 Taman Pemalang yang dilaksanakan pada tanggal 13 Oktober 
2018, hasil pengolahan AKPD dalam profil kelas rata-rata memiliki masalah yang tinggi dalam hal topik belajar. Pada saat peneliti berada di sekolah tersebut banyak siswa berada di luar kelas pada saat guru memberikan tugas mandiri kepada siswa, siswa melihat pekerjaan teman tanpa usaha diri sendiri dan siswa tidak terlihat aktif pada saat jam pelajaran berlangsung.

Selain itu peneliti melakukan wawancara dengan siswa, guru mata pelajaran dan guru BK. Berdasarkan hasil wawancara dengan siswa bahwa siswa cenderung mengerjakan PR di sekolah, siswa sering mencontek saat ujian dan bekerjasama dengan teman yang lain, siswa keinginan untuk belajar rendah dan terdapat siswa yang menggunakan jam pelajaran untuk mengobrol atau bermain di dalam kelas. Wawancara dengan salah satu guru mata pelajaran fisika bahwa siswa asik sendiri pada saat pembelajaran berlangsung, siswa saling bekerja sama pada saat ulangan atau ujian, siswa mengerjakan pekerjaan rumah disekolah, siswa cenderung pasif didalam kelas.

Adapun hasil wawancara yang dilakukan dengan guru BK yaitu guru BK menyatakan bahwa siswa lebih suka bermain daripada belajar, siswa masih saling bekerja sama pada saat ulangan atau ujian, guru BK belum perrnah memberikan layanan bimbingan kelompok kepada siswa dikarenakan jam untuk BK tidak ada meskipun guru BK menangani siswa diruang guru BK.Melihat fenomena tersebut menurut peneliti dapat diselesaikan dengan cara memberi layanan bimbingan kelompok dengan teknik psikodrama. Bimbingan kelompok menurutNurihsan, (2006: 23) bimbingan kelompok merupakan pemberian bantuan terhadap individu yang dilaksanakan dalam situasi kelompok. Bimbingan kelompok dapat berupa penyampaian informasi ataupun aktivitas kelompok membahas masalahmasalah pendidikan, pekerjaan, pribadi, dan sosial dengan memanfaatkan dinamika kelompok.

Bimbingan kelompok merupakan lingkungan yang kondusif yang memberikan kesempatan bagi anggotanya untuk menambah penerimaan diri dan orang lain, memberikan ide, perasaan, dukungan, bantuan alternatif pemecahan masalah dan mengambil keputusan yang tepat dan bertanggung jawab atas pilihan yang ditentukannya sendiri.Pemberian layanan bimbingan kelompok ini untuk hasil yang lebih optimal menggunakan teknik psikodrama. Menurut Corey (dalam Romlah, 2001: 108) psikodrama merupakan permainan peranan yang dimaksudkan individu yang bersangkutan dapat memperoleh pengertian lebih baik tentang dirinya, menyatakan kebutuhankebutuhannya, dan menyatakan reaksi terhadap tekanan-tekanan terhadap dirinya.

Penjelasan di atas menjadi acuan peneliti untuk menjadikan layanan bimbingan kelompok dengan teknik psikodrama untuk mengembangkan kemandirian belajar siswa kelas XI SMK PGRI 2 Taman Pemalang. Berdasarkan berbagai permasalahan yang ada di SMK PGRI 2 Taman Pemalang maka diperlukan suatu usaha yang mampu meningkatkan kemandirian belajar siswa.

\section{METODE PENELITIAN}

Penelitian ini dilaksanakan di SMK PGRI 2 Taman Pemalang. Peneliti memilih sekolah tersebut karena masih 
banyak siswa yang kemandirian belajarnya rendah. Penelitian ini dengan judul Pengaruh Bimbingan Kelompok dengan Teknik Psikodrama terhadap Kemandirian Belajar Siswa kelas XI SMK PGRI 2 Taman Pemalang. Waktu penelitian dilaksanakan pada bulan AgustusSeptember 2019.

Dalam penelitian ini peneliti menggunakan metode true eksperimentaldesign yang digunakan untuk mengetahui pengaruh layanan bimbingan kelompok dengan teknik psikodrama terhadap kemandirian belajar, dengan cara memberikan perlakuan kepada sekelompok siswa yang digunakan sebagai kelompok eksperimen dan kelompok kontrol yang tidak diberi perlakuan. Dalam kelompok ini nanti akan dilakukan pretest sebelum diberikan perlakuan dan posttest setelah dilakukan perlakuan dan hasilnya akan dianalisis dan dibandingkan. Populasi dalam penelitian ini berjumlah 240 siswa, sedangkan sampel yang digunakan berjumlah 20 siswa, 10 untuk dijadikan kelompok eksperimen dan 10 untuk dijadikan kelompok kontrol. Teknik yang digunakan menggunakan teknik cluster random sampling dan peneliti melakukan analisis menggunakan uji-t untuk mengetahui pengaruh layanan bimbingan kelompok dengan teknik psikodrama.

\section{HASIL PENELITIAN}

Berdasarkan dari data deskripsi pretest dan post-test untuk mencari rentang interval pada kelompok eksperimen menggunakan rumus rentang interval. Adapun rumus interval sebagai berikut:

\begin{tabular}{|c|c|c|c|c|}
\hline \multicolumn{3}{|c|}{ Rumus } & \multicolumn{2}{|c|}{ kelas } \\
\hline$S$ & $t_{1}$ & $-s$ & $t_{1}$ & $n$ \\
\hline & 4 ( & ) kt & & \\
\hline
\end{tabular}

Skor tertinggi $=116$

Skor terendah $=29$

Rentang $=\frac{1-2}{4}=21,75=22$

Setelah diperoleh hasil rentang interval, maka dapat diperoleh hasil tabel kategori interval sebagai berikut:

\section{Tabel 1}

\section{Kategori Interval}

$\begin{array}{cc}\text { Kategori } & \text { Skor } \\ \text { Sangat Tinggi } & 95-116 \\ \text { Tinggi } & 73-94 \\ \text { Rendah } & 51-72 \\ \text { Sangat Rendah } & 29-50\end{array}$

Berikut ini adalah perbandingan hasil pretest dan post-test kelompok eksperimen.

\section{Tabel 2}

\section{Perbandingan Hasil Pre Test dan Post Test}

\section{No Pre-test Post-test}

\begin{tabular}{clcccc} 
& Skor & Kategori & Skor & Kategori \\
1 & 71 & $\mathrm{R}$ & 92 & $\mathrm{~T}$ \\
2 & 64 & $\mathrm{R}$ & 90 & $\mathrm{~T}$ \\
3 & 73 & $\mathrm{~T}$ & 86 & $\mathrm{~T}$ \\
4 & 73 & $\mathrm{~T}$ & 89 & $\mathrm{~T}$ \\
5 & 72 & $\mathrm{R}$ & 94 & & $\mathrm{~T}$ \\
6 & 83 & $\mathrm{~T}$ & 99 & \multicolumn{2}{c}{$\mathrm{ST}$} \\
7 & 75 & $\mathrm{~T}$ & 88 & $\mathrm{~T}$ & \\
8 & 82 & $\mathrm{~T}$ & 94 & $\mathrm{~T}$ & \\
9 & 67 & $\mathrm{SR}$ & 87 & $\mathrm{~T}$ & \\
10 & 69 & $\mathrm{SR}$ & 89 & $\mathrm{~T}$ & \\
$\mathrm{Jml}$ & 729 & & 908 & &
\end{tabular}

Berdasarkan hasil pre-test dan posttest pada kelompok eksperimen yang berjumlah 10 responden, diketahui bahwa ada pengaruh setelah diberikan treatment dengan menggunakn layanan bimbingan

Annisa Ul Khusna*, Arri Handayani**, dan Gregorius Rahastono Ajie*** 
kelompok dengan teknik psikodrama.

\section{Gambar 1}

Grafik Rata-rata Hasil Pre-test dan

Post-test

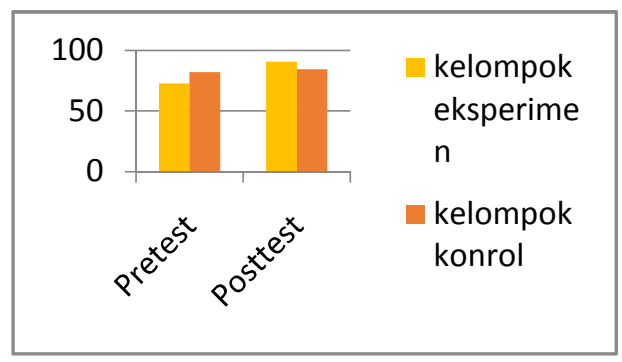

Tabel 3

\section{Uji Hipotesis $t$-test}

$\begin{array}{ccccc}\text { No } & \boldsymbol{x}_{\mathbf{1}} & \boldsymbol{x}_{\boldsymbol{Z}} & \boldsymbol{X}_{\mathbf{1}}{ }^{\boldsymbol{Z}} & \boldsymbol{X}_{\mathbf{Z}}{ }^{\boldsymbol{Z}} \\ 1 & 92 & 90 & 8464 & 8100 \\ 2 & 90 & 82 & 8100 & 6724 \\ 3 & 86 & 93 & 7396 & 8649 \\ 4 & 89 & 84 & 7921 & 7056 \\ 5 & 94 & 88 & 8836 & 7744 \\ 6 & 99 & 76 & 9801 & 5776 \\ 7 & 88 & 91 & 7744 & 8281 \\ 8 & 94 & 89 & 8836 & 7921 \\ 9 & 87 & 75 & 7569 & 5625 \\ 10 & 89 & 79 & 7921 & 6241 \\ \text { Jumlah } & 908 & 847 & 82588 & 72117 \\ \text { Kode } & \sum \boldsymbol{x}_{\mathbf{1}} & \sum \boldsymbol{x}_{\mathbf{Z}} & \sum \boldsymbol{x}_{\mathbf{1}}{ }^{\mathbf{2}} & \sum \boldsymbol{X}_{\boldsymbol{L}}{ }^{2}\end{array}$

Dengan $\mathrm{db}=\left(N_{1+} N_{1}\right)-2=(10+10)$ $-2=18$ di taraf signifikansi $5 \%$ untuk ttabel $(18=2,101)=2,543$ $\operatorname{makaa}_{\text {nit }}>t_{t_{1}}, \quad 2,543>2,101$.

Berdasarkan perhitungan analisis $\mathrm{t}$ test dapat diperoleh $t_{\text {nit }}$ sebesar 2,543 sementara $t_{t_{1}} \quad$ dengan taraf signifikansi $5 \%$ sebesar 2,101, karena $t_{\text {nit }}>t_{t_{1}}$ 2,543> 2,101. maka dapat disimpulkan bahwa "Ada Pengaruh layanan bimbingan kelompok dengan teknik psikodrama terhadap kemandirian belajar siswa kelas
XI SMK PGRI 2 Taman Pemalang”.

\section{PEMBAHASAN}

Analisis hasil pre-test antara kelompok eksperimen dan kelompok kontrol menunjukan rata-rata kemandirian belajar siswa kelompok eksperimen sebesar 72,9 dan kelompok kontrol sebesar 82,2. Selisih antara kelompok eksperimen dan kelompok kontrol adalah 9,3.Setelah diberikan treatment bimbingan kelompok dengan teknik psikodrama pada kelompok ekpserimen mengalami pengaruh dari 72,9 menjadi 90,8, terjadi pengaruh sebesar 17,3. Sedangkan kelompok kontrol dari 82,2 menjadi 84,7 terjadi peningkatan 2,5. Selisih antara kelompok eksperimen dan konrtol adalah 12,8. Hasil analisis data menunjukan bahwa ada perbedaan antara kelompok eksperimen yang diberikan treatment berupa layanan bimbingan kelompok dengan teknik psikodrama dan kelompok kontrol yang tidak diberikan perlakuan (treatment). Kemandirian belajar memiliki lima indikator, dari kelima indikator tersebut yang masuk dalam skor perubahan tertinggi adalah pada indikator ke II (Tanggung Jawab) dengan hasil pre test 20,2 mengalami perubahan 28,1. Dalam pelaksanaan treatment yang dilakukan oleh peneliti selama lima kali pertemuan sudah menunjukan adanya perubahan yang terjadi pada siswa. Contohnya pada awal pertemuan siswa tidak ragu-ragu dan malu untuk mengeluarkan pendapat, siswa tanpa ditunjuk langsung mengajukan diri untuk memerankan tokoh dalam permainan peran.Penelitian ini membahas tentang kemandirian belajar siswa, hal ini ditunjukan adanya permasalahan siswa berbicara dengan teman sebangku pada 
saat jam pelajaran berlangsung, siswa masih pasif dalam pembelajaran, siswa melihat pekerjaan temna pada saat ulangan, mengerjakan pekerjaan rumah di sekolah, pada saat jam kosong siswa banyak yang di luar kelas dan pergi ke kantin. Untuk mengembangkan kemandirian belajar siswa maka digunakan layanan bimbingan kelompok dengan teknik psikodrama membuat siswa memiliki pemahaman tentang kemandirian belajar dan siswa bisa membuat keputusan dalam kemandirian belajarnya.. Menurut Tohirin (2007:164), bimbingan kelompok merupakan suatu cara memberikan bantuan (bimbingan) kepada individu (siswa) melalui kegiatan kelompok. Kegiatan bimbingan kelompok dapat berfungsi untuk mencegah, memelihara, dan mengembangkan potensi yang dimiliki sehingga tercapai perkembangan yang optimal. Melalui dinamika kelompok sebagai medianya, setiap anggota kelompok dituntut untuk dapat menyumbangkan apa yang mereka miliki seperti pendapat, pengalaman, dan sebagainya. Dalam bimbingan kelompok dapat berupa penyampaian informasi atau aktivitas kelompok membahas masalahmasalah pendidikan, pekerjaan, pribadi dan sosial.

Menurut Moreno (dalam Prawitasari, 2011: 177), psikodrama memberikan kesempatan untuk melihat kehidupan pribadi dengan cara pandang berbeda setelah kehidupan pribadi itu didramakan dan dimainkan oleh orang tak dikenal yang berada dalam kelompok. Selain itu karena dengan teknik ini siswa dapat mengetahui, mengembangkan dan memecahkan masalah yang ada pada dirinya mengenai kemandirian belajar.bahwa layanan bimbingan kelompok dengan teknik psikodrama adalah suatu proses pemberian bantuan kepada individu (siswa) melalui kegiatan kelompok dengan memanfaatkan dinamika kelompok, untuk membahas berbagai hal yang berguna bagi pengembangan atau pemecahan masalah melalui sebuah drama yang dimainkan terkait permasalahan psikis/pribadi yang dialami oleh individu.

Pemberian treatment dilakukan sebanyak 5 kali. Dalam treatment anggota kelompok bermain peran sesuai dengan topik yang sedang dibahas, setelah permainan dilakukan kemuadian dilanjutkan untuk berdiskusi mengenai apa yang diperoleh setelah melakukan permainan yang telah dilakukan dan menyimpulkan hasil yang didapat dari topik yang dibahas dengan menggunakan teknik psikodrama. Penelitian ini diperkuat oleh penelitian terdahulu oleh Azmatul Khairiah Sari (dalam Elfira, 2013: 281) fakta menunjukan bahwa kemandirian siswa mengatasi masalah belajar, yang juga membuktikan bahwa layanan bimbingan kelompok bermanfaat dalam upaya meningkatkan kemandirian belajar siswa. Dengan harapan siswa berbagi pengalaman, wawasan, sikap atau ketrampilan yang diperlukan dalam kemandirian belajar siswa.

Dari uraian di atas dapat dikatakan bahwa bimbingan kelompok teknik psikodrama dapat mengembangkan kemandirian belajar siswa kelas XI SMK PGRI 2 Taman Pemalang.

\section{KESIMPULAN}

Berdasarkan hasil perhitungan penelitian analisis rumus uji-t menunjukant $t_{\text {hit }} \quad(2,543)>t_{t_{1}}$ 
$(2,101)$ dengan $\mathrm{db}=\left(N_{1}+N_{1}\right)-2=18$ dengan taraf signifikansi 5\% makathitung lebih besar dari ttabel. Dengan demikian hipotesis yang berbunyi "Pengaruh Layanan Bimbingan Kelompok dengan Teknik Psikodrama terhadap Kemandirian Belajar siswa kelas XI SMK PGRI 2 Taman Pemalang" dapat diterima. Demikian dapat disimpulkan bahwa layanan bimbingan kelompok dengan teknik psikodrama dapat mempengaruhi kemandirian belajar siswa kelas XI SMK PGRI 2 Taman Pemalang. Dari hasil pembahasan dan simpulan di atas, maka dibawah ini beberapa saran yang dapat disampaikan sebagai berikut:

1. Bagi Sekolah, dengan melihat adanya pengaruh layanan bimbingan kelompok dengan teknik psikodrama terhadap peningkatan kemandirian belajar siswa, maka untuk memberikan layanan bimbingan kelompok perlu adanya tempat khusus untuk praktek dan menjadi kegiatan rutin agar siswa lebih mengenal layanan yang ada didalam bimbingan dan konseling.

2. Bagi Siswa, sebagai referensi perkembangan ilmu pengetahuan dalam bimbingan dan konseling serta sebagai pengetahuan untuk siswa dalam berperilaku.

3. Bagi Peneliti, lebih memperdalam pengetahuan dan mengembangkan pelaksanaan layanan bimbingan kelompok dengan teknk psikodrama terhadap kemandirian belajar atau dengan teknik yang lain.

Penelitian ini tetap menunjukan bahwa layanan bimbingan kelompok dengan teknik psikodrama dapat mengembangkan kemandirian belajar siswa..

\section{DAFTAR PUSTAKA}

Asrori. 2015. Perkembangan Peserta didik (Pengembangan Kompetensi Pedagogis Guru). Yogyakarta: Media Akademi.

Desmita.2014. Psikologi Perkembangan Peserta didik. Bandung: PT Remaja Rosda Karya.

Elfira, Ninil. 2013. Peningkatan Kemandirian belajar siswa Melalui Layanan Bimbingan kelompok. Jurnal ilmiah Konseling.Vol 2. No 1.

Jamaris, Martini. 2013. Orientasi Baru dalam Psikologi Pendidikan. Bogor: Penerbit Ghalia Indonesia.

Karyanti, Muhammad Andi Setiawan. 2018. Model Konseling Kelompok Teknik Expresif Writing Berlandaskan Falsafah Dandang Tingang Untuk Meningkatkan Perilaku Respect. JURKAM: Jurnal Konseling Andi Matappa, 2(2):129136.

Negoro, Suratina tirto. 2008. Kecenderungan Hidup Mandiri. Bandung: Tarsito.

Nurihsan, Achmad Juntika, 2006. Bimbingan dan Konseling Berbagai Latar Kehidupan.Bandung : PT. Refika Aditama.

Pemerintah Indonesia. 2003. UndangUndang Nomor 20 Tahun 2003 tentang Sistem Pendidikan Nasional. Jakarta: Sekretariat Negara.

Prawitasari, johana e. 2011. Psikologi Klinis (Pengantar Terapan Makro dan Mikro. Jakarta: Penerbit Erlangga.

Riadin, Agung, dkk. 2017. Karakteristik 
Anak Berkebutuhan Khusus di Sekolah Dasar Negeri (Inklusi) di Kota Palangka Raya. Anterior Jurnal, 17(1):22-27.

Romlah, Tatiek. 2001. Teori dan Praktek Bimbingan Kelompok. Malang : Malang Universitas

Rusman. 2010. Model - model Pembelajaran (Mengembangkan Profesionalisme Guru). Jakarta: PT Raja Grafindo Persada.

Safithry, Esty Aryani \& Niky Anita. 2019. Konseling Kelompok Dengan Teknik Self Management Untuk Menurunkan Prasangka Sosial Peserta Didik. Suluh: Jurnal Bimbingan Dan Konseling, 4(2):3341.

Setiawan, M Andi. 2015. Model konseling kelompok dengan teknik problem solving untuk meningkatkan selfefficacy akademik siswa. Jurnal Bimbingan Konseling 4(1).

Setyawan, Dedy \& Muhammad Fitriadi. Penggunaan Media Tiga Dimensi dalam Meningkatkan Hasil Belajar Matematika Peserta Didik. Bitnet: Jurnal Pendidikan Teknologi Informasi, 2(1):1-7.

Tohirin. 2007. Bimbingan dan Konseling di Sekolah dan Madrasah (Berbasis Integrasi). Jakarta: PT Raja Grafindo. 